\title{
NORMAS PARA LA PRESENTACIÓN DE ORIGINALES
}

1) Para remitir artículos a nuestra revista es necesario dirigirse a la página <http://mc.manuscriptcentral.com/enscie $>\mathrm{y}$ seguir las instrucciones para registrarse como usuario dentro del sistema ( $\log \operatorname{In})$

Asegúrese de que adjunta una versión de su artículo que no contiene el nombre de sus autores ni información relativa a ellos (institución a la que pertenecen, citas bibliográficas propias, etc.).

2) Los artículos tendrán una extensión máxima de 45.000 caracteres sin incluir espacios pero incluyendo las tablas, las figuras y los anexos.

3) Junto con el artículo se remitirá un resumen (máximo de 10 líneas), una traducción del mismo en inglés, cinco palabras clave (en castellano e inglés) y el título del artículo también en inglés.

4) Se recomienda la confección de los originales con un procesador de textos (Macintosh y PC compatibles).

5) Es imprescindible que los esquemas, dibujos, gráficas e imágenes sean guardados en formato TIF, EPS o JPEG, a una resolución de 300 ppp. $16 \mathrm{~cm}$. de ancho y en el color original. Éstos se adjuntarán en una carpeta aparte del documento del texto, ya que las imágenes incrustadas en el texto no son válidas para su posterior edición.

6) Todas las citas bibliográficas se relacionarán al final del artículo por orden alfabético de apellidos, indicando: autor(es), año, título del artículo, título de la revista completo y en cursiva (o subrayado), volumen, número y páginas del mismo.

Por ejemplo:

NOVAK, J.D. (1977). An Alternative to Piagetian Psychology for Science and Mathematics Education. Science Education, 61(4), pp. 453-457.

En el caso de referencias de libros, se escribirá el título en cursiva (o subrayado) y se pondrá: el lugar de edición, dos puntos y la editorial.

Por ejemplo:

OSBORNE, R. y FREYBERG, P. (1991). El aprendizaje de las ciencias. Implicaciones en la ciencia de los alumnos. Madrid: Narcea ediciones.

Todas las referencias bibliográficas deben corresponder a menciones hechas en el texto.

7) Dentro del texto, las referencias se indicarán citando, entre paréntesis, los apellido(s) de los autores o autoras y el año de publicación, separados por una coma.

Por ejemplo: [...] obstáculo epistemológico (Bachelard, 1938).

Cuando el nombre del autor aparezca explícitamente en el texto, se pondrá el año del trabajo entre paréntesis.

Por ejemplo: [...] según Bachelard (1938).

8) Los resúmenes de tesis didácticas se remitirán igualmente a través de la página:

$<$ http://mc.manuscriptcentral.com/enscie>.

Constarán de los siguientes datos: título, autor o autora, tipo de tesis (doctoral o de maestría), director(es) o directora(s), departamento, universidad, programa en que se ha presentado, fecha de presentación, resumen de una extensión máxima de 4.500 caracteres (sin espacios).

\section{Clara Garcia Pujol}

Revista Enseñanza de las Ciencias

$<$ http://ensciencias.uab.es>. 